\title{
CONTRIBUTION AND INDEMNITY IN CALIFORNIA
}

As a result of a collision between vehicles driven by Ryan and Kelley, Ryan's sportscar careened across the sidewalk into San Francisco Bay and passenger Gray drowned. In an action for wrongful death, Gray's heirs charged Ryan with recklessly speeding while intoxicated, Kelley with negligent driving, and the city of Sausalito with negligent failure to provide a guard rail between the roadway and the Bay. The city cross-claimed for a declaration that if it were held liable, it should be entitled to indemnity from Ryan and Kelley, and the trial court sustained the demurrers of Ryan and Kelley. On appeal of the indemnity point, the court in City of Sausalito v. Ryan ${ }^{1}$ held that the city should be permitted to shift the entire loss to the two drivers if they were more negligent.

Ryan is but one example of the rapidly increasing number of situations involving multiple tort liability which raise the problem of properly allocating the loss among tortfeasors. ${ }^{2}$ The law of contribution and indemnity which has developed to handle these situations is extremely complex, and nowhere is the need for clarification and revision more pressing than in California. This Comment will first trace the development of the noncontractual indemnity doctrine and explore its relationship to both implied contractual indemnity and contribution. It will then evaluate the Ryan extension of indemnity in terms of tort law policy goals. Although the Ryan decision no longer has legal force, ${ }^{3}$ it has neither been approved

1. City of Sausalito v. Ryan, 258 A.C.A. 92, 65 Cal. Rptr. 391 (1968). The Supreme Court of California heard the indemnity appeal on May 7, 1968. Subsequently, and before the supreme court had rendered an opinion, the city of Sausalito filed a motion for summary judgment in the trial court with respect to the original complaint, alleging a governmental design immunity defense. The plaintiff's attorney stipulated that the motion be granted without argument. The motion was granted and no appeal was taken, so the entire damage case against the city was terminated. The city's attorneys immediately notified the supreme court and requested that it dismiss the appeal on the indemnity point. The appeal was dismissed on March 7, 1969. 70 A.C. No. 12 at Minutes 1 (1969).

2. The growing complexity of our industrial society and the accompanying changes in the theory of tort law away from fault bases toward strict liability produce more and more cases of multiple liability. See J. Fleming, AN INTROduction to the LaW of TorTs I-15 (1967). The standard situations of concerted action, vicarious liability, or common duty, see generally w. Prosser, HaNdBooK of the LaW of Törts 249-50 (3d ed. 1964), have likewise increased. At the same time new situations of multiple liability are arising as strict liability is extended. For example, as the "assault on the citadel of privity" continues, consumers are able to hold retailer, wholesaler, and manufaeturer for damages caused by defective products. E.g., 3 Frumer \& Friedman, Products Liability, § 44; Jaeger, Privity of Warranty: Has the Tocsin Sounded?, I Duquesne U.L. Rev. 1 (1963); Prosser, The Assault Upon the Citadel, 69 YALE L.J. 1099 (1960).

3. See note 1 supra. In California the granting of a motion for hearing by the supreme court has the effect of vacating and nullifying the court of appeal-decision involved. The opinion 
nor disapproved by the California supreme court and it stands as an example of what a California court might do when faced with such a question in the future. Finally, this Comment will propose needed revision of the California contribution statutes; such a revision is designed to remove present pressures for an extension of noncontractual indemnity to inappropriate situations like that in Ryan.

\section{1}

\section{TERMINOLOGY AND SCOPE}

Contribution and indemnity are two doctrines which are used as tools to reach the same goal: a fair allocation of the ultimate burden of a tort recovery among those legally responsible. ${ }^{4}$ Once the victim has been compensated, who should, in all fairness, be made to pay? The answers given by the noncontractual indemnity and contribution doctrines are based on equitable considerations of unjust enrichment and restitution..$^{5}$ ln its tort setting, contribution allows a wrongdoer who has been held liable for damages to recover from each of his cotortfeasors a ratable portion of the total liability he has discharged; the goal is equalization of what should be a common burden. ${ }^{6}$

A typical situation giving rise to a right of contribution is an automobile collision where the negligent acts of two or more defendants combine to produce a single, indivisible injury to the plaintiff. The defendants are concurrent tortfeasors ${ }^{7}$ and each of them is liable to the plaintiff for the entire amount, but any defendant who pays more than his share of the total loss is entitled to reimbursement from his co-tortfeasors. Ordinarily this reimbursement or contribution

and decision become nullities and are of no force either as a judgment or as an authoritative statement of any principle of law. E.g., Ponce v. Marr, 47 Cal. 2d 159, 301 P.2d 837 (1956); Knouse v. Nomocks, 8 Cal. 2d 482, 483-84, 66 P.2d 438, $438-39$ (1937).

4. See, e.g., Davis, Indemnity between Negligent Tortfeasors: Indennity between Negligent Tortfeasors: A Proposed Rationale, 37 lowA L. Rev. 517, 538 (1952); Leflar, Contribution and Indemnity between Tortfeasors, 81 U. PA. L. Rev. 130, 147 (1932).

5. Furnish, Distributing Tort Liability: Contribution and Indemnity in Jowa, 52 Iow $\mathrm{L}$. Rev. 31, 33, 48-49 (1966); Leflar, Contribution and Indenmity between Tortfeasors, 81 U. PA. L. Rev. 130, 136-37 (1932); see Builders'Supply Co. v. McCabe, 366 Pa. 322, 366, 77 A.2d 368, 375 (1951); RESTATEMENT OF Restitution $\$ 1$ and comment $b$ at 12 (1937); $i d$. $\$ \$ 86-102$.

6. C. Gregory, Legislative Loss Distribution in Negligence Actions 4 (1936).

7. The term "joint tortfeasors" is often applied to this kind of situation. For this discussion it is more useful to restrict the "joint tortfeasor" label to cases of purposeful action in concert. "Concurrent negligence" will be used to describe the situation arising from the accidental combination of negligence by two or more parties. See Davis, Indemnity between Negligent Tortfeasors: A Proposed Rationale, 37 Iowa L. Rev. 517, 537 (1952). 
results in an equal sharing of the burden, with each defendant's share calculated by dividing the total recovery by the number of defendants found to have negligently contributed to the damage. In England ${ }^{8}$ and some American jurisdictions, ${ }^{9}$ however, each wrongdoer may be held in proportion to his fault.

Judge Learned Hand stated that, "[I]ndemnity is only an extreme form of contribution."'I0 Indemnity allows one who has discharged a common obligation to recover the entire amount he has paid from the party primarily liable." In contrast to contribution, it provides for shifting the total burden from one party to another. Indemnity can be conveniently broken down into three general categories: Express contractual indemnity, implied contractual indemnity (implied-in-fact indemnity), and noncontractual indemnity (implied-in-law indemnity). ${ }^{\mathbf{2}}$

An express contractual indemnity right results from an express promise by one party to indemnify the other for a particular kind of loss.

8. J. Fleming, supra note 2 , at 117.

9. Arkansas, Delaware, Hawaii, and South Dakota enacted an optional provision in the 1939 Uniform Contribution Among Tortfeasors Act, providing apportionment rather than contribution in equal shares "when there is such a disproportion of fault among joint tortfeasors as to render incquitable an equal distribution among them." CONTRIBUtion AMONG TortFEasors ACT $\$ 2(4)$ (1939), 9 U.L.A. 230, 235 (1957); ARK. STAT. ANN. $\$ 34-1001$ to 1009 (1962); Del. Code ANN. tit. 10, $\$$ 6301-08 (1953); Hawall Rev. Laws $\$ \$ 246-10$ to 16 (1955); S.D. CODE $\S \S 33.04$ A01-.04A 10 (Supp. 1960).

Wisconsin, in 1962, applied its comparative negligence doctrine to contribution by judicial decision: "[T]he amount of liability for contribution of tortfeasors who sustain a common liability by reason of causal negligence should be determined in proportion to the percentage of causal negligence attributable to each." Bielski v. Schulze, 16 Wis. 2d 1, 6, 114 N.W.2d 105, 107 (1962).

An appellate court in Illinois followed Wisconsin in adopting comparative negligence applicable to both the original claim and contribution. Maki v. Frelk, 85 Ill. App. 2d 439, 45I, 229 N.E.2d 284, 290 (1967). This advance was reversed by the Supreme Court of Illinois on stare decisis grounds over a powerful dissent. Maki v. Frclk, 40 III. 2d 193, 239 N.E.2d 445 (1968). The Third Circuit has adopted the Wisconsin scheme for the Virgin Islands, deeming it a "rule of reasoned fairness." Gomes v. Brodhurst, 394 F.2d 465, 467 (3d Cir. 1967).

10. Slattery v. Marra Bros., 186 F.2d 134, 138 (2d Cir. 1951).

II. Leflar, supra note 5, at 131 .

12. Compare Furnish, supra note 5, at 37-48, with Molinari, Tort Indemnity' in Caifornia, 8 SANTA Clara Lawyer 159, 159-60 (1967).

In California the courts have used slightly different categories. "Express indemnity" and "implied indemnity" are the two primary groupings, with the latter subdivided into "implied contractual indeminity" and "implied noncontractual indemnity." See Cahill Bros. v. Clementina Co., 208 Cal. App. 2d 367, 376, 25 Cal. Rptr. 301, 305 (1962). In effect, these categories amount to the same thing as those used in the text.

It should be emphasized that these categories are only descriptive models and there are in fact no clear demarcations among them. Blurring is especially evident between implied contractual indemnity and noncontractual indemnity. 
The problems in this area primarily involve contract interpretation and are outside the scope of this Comment. ${ }^{13}$

Implied contractual indemnity arises where a promise to indemnify may be implied from a more general contractual relationship between the parties. ${ }^{14}$ Although the basis of the right is contractual, equitable considerations are necessarily involved ${ }^{15}$ and may bar recovery. ${ }^{16}$ If the indemnitee is found to have been actively negligent himself, he will not be entitled to indemnity despite the indemnitor's breach of their implied agreement. ${ }^{17}$ It is this equitable aspect of implied contractual indemnity which is relevant to this Comment's discussion of contribution and indemnity.

Noncontractual indemnity arises in the absence of a contract where there are equitable reasons for allowing indemnity. A typical example occurs when an employer, held vicariously responsible for the negligence of his employee, is entitled to full indemnification from the employee..$^{18}$

\section{II}

\section{DEVELOPMENT OF THE INDEMNITY AND CONTRIBUTION DOCTRINES}

\section{A. Indemnity Exceptions to the No Contribution Rule}

Merryweather $v$. Nixan, ${ }^{19}$ the English case credited with originating the rule denying both contribution and indemnity among concurrent tortfeasors, ${ }^{20}$ actually involved intentional action in concert and a claim for contribution. ${ }^{21}$ The rule was restricted to the case's

13. It should be noted, however, that California courts strictly construe indemnity contracts against an "actively negligent" indemnitee. So, unless the agreement explicitly states: "I promise to indemnify X for damage caused by his own active negligence," the person seeking indemnity under express agreement must show that he was not "actively negligent," thereby meeting the criteria for implied contractual indemnity. E.g., Markley v. Beagle, 66 Cal. 2d 951, 962, 429 P.2d 129, 136, 59 Cal. Rptr. 809, 816 (1967); Goldman v. Ecco-Phoenix Elec. Corp., 62 Cal. 2d 40, 44, 396 P.2d 377, 379, 4 I Cal. Rptr. 73, 75 (1964).

14. Eg., Weyerhaeuser S.S. Co. v. Nacirema Operating Co., 355 U.S. 563, 569 (1958); San Francisco Unified School Dist. v. California Bldg. Maint. Co., 162 Cal. App. 2d 434, 328 P.2d 785 (1958).

15. Leflar, supra note 5 , at 147.

16. Implied indemnity, like implied warranty, is an area of the law where tort and contract ideas overlap. See W. Prosser, supra note 2, at 634-57. Characterization of the action as in contract or in tort may have procedural consequences, such as differing statutes of limitations. Davis, supra note 7, at 538.

17. E.g., Weyerhaeuser S.S. Co. v. Nacirema Operating Co., 355 U.S. 563, 567 (1958); Cahill Bros. v. Clementina Co., 208 Cal. App. 2d 367, 382, 25 Cal. Rptr. 301, 309 (1962).

18. E.g., Bradley v. Kosenthal, 154 Cal. 420 (1908).

19. 8 Term. Rep. 186, 101 .Eng. Rep. 1337 (K.B. 1799).

20. See, e.g. Leflar, supra note 5 , at 130.

21. W. Prosser, supra note 2, at 273-74. 
facts in both English ${ }^{22}$ and early American ${ }^{23}$ cases, but 20th-century American courts began to disregard the limitation on the rule and to deny contribution or indemnity among even merely negligent, independent tortfeasors..$^{24}$ The result of this trend was a firm rule barring apportionment of loss among multiple tortfeasors. ${ }^{25}$

American jurisdictions, while retaining the rule against contribution, quite early carved out exceptions which permitted one tortfeasor to recover indemnity from his co-tortfeasor under certain circumstances. ${ }^{26}$ By the 1930's these indemnity exceptions were firmly established, ${ }^{27}$ while contribution, even in the few jurisdictions where it was permitted, was usually greatly restricted..$^{28}$ Thus, the indemnity doctrine developed in most American jurisdictions in a setting where contribution was not permitted; either indemnity was granted or there could be no apportionment of the loss at all. Indemnity came to be available in three broad categories: Where a court had imposed liability without fault, where one of several tortfeasors had been held for negligible fault, and where one wrongdoer had been found to have been less at fault than the others. ${ }^{29}$

\section{Liability without Fault}

A person held liable without personal fault, solely by operation of a rule of law, is entitled to indemnification from the actor who

22. Adamson v. Jarvis, 4 Bing. 66, 130 Eng. Rep. 693 (C.P. 1827); Burrows v. Rhodes, 1 Q.B. 816 (1899); Wooley v. Batte, 2 C\&P 417, 172 Eng. Rep. 188 (1826). But apparently some courts did extend the rule to cases of negligence, accident or mistake. J. FleniNG, THE LAW OF TORTS 687 (3d ed. 1965).

23. Compare, e.g.. Peck v. Ellis, 2 Johns. Ch., 131, (N.Y. 1816), with Thweatt's Adm'r v. Jones, 1 Rand. 328 (Va. 1825).

24. See, e.g., Louisville v. Louisville Ry., 156 Ky. 141, 160 S.W. 771 (1913); Larkin Co. v. Terminal Warehouse Co., 161 App. Div. 262, 146 N.Y. Supp. 380 (1914), a/f'd, 221 N.Y. 707, 117 N.E. 1074 (1917); Fidelity \& Cas. Co. v. Chapman, 167 Ore. 661, 120 P.2d 223 (1941). Dean Prosser suggests that this occurred because of confusion created by new joinder rules which allowed joinder in the same action of independent, negligent tortfeasors; those so joined were termed "joint tortfeasors," a term which previously had been restrieted to those who acted in coneert. See W. Prosser, supra note 2, at 260-65, 274.

25. See, e.g., Leflar, supra note 5, at 130, cases cited note 46 at 141. As late as 1951 the lowa supreme court said: "Generally, in the absence of statute, there can be no contribution or indemnity among joint tortfeasors." Rozmajzl v. Northland Greyhound lines, 242 lowa 1135 , 1142, 49 N.W.2d 501, 506 (1951).

26. See notes $31-47$ infra.

27. See Leflar, supra note 5, at 146-59.

28. See id. at 144 n.66. Only three states then had broad contribution statutes which did not require a joint judgment. They were enacted in 1919 (Virginia), 1926 (Kentucky), and 1929 (North Carolina). Id. Three other states-Wisconsin, Pennsylvania, and Minnesota-allowed contribution in the absence ol statute. Id. at 141.

29. It is possible to separate implied contraetual indemnity from noncontractual indemnity analytically, but in fact the line between them is very hazy. Existence of a broader contractual 
caused the damage..$^{30}$ Those held vicariously liable, for example, such as a principal liable under the doctrine of respondeat superior for the torts of his agent, ${ }^{31}$ a person held for the negligence of his independent contractor, ${ }^{32}$ or an automobile owner obligated by statute for a driver's wrongful actions, ${ }^{33}$ are entitled to indemnity from the actual wrongdoer. Indemnity also is granted in a multitude of products liability cases..$^{34}$ Most frequently, a retailer who has been held either for breach of an implied warranty ${ }^{35}$ or strictly liable in tort ${ }^{36}$ is entitled to recover from the manufacturer or supplier of the defective product. ${ }^{37}$ These are just a few of the numerous situations where the negligent actor must indemnify the person who paid the damage. ${ }^{38}$

In some instances the actor may himself be free of fault and thus entitled to indemnity. An employee or agent, for example, who is directed by his employer or principal to perform an act which on its face appears to be lawful but which turns out to be tortious, is given indemnity from the person so directing him. ${ }^{39}$

relationship is only an additional fact which goes into the balance in determining whether indemnity is called for. Therefore, in discussing the situations where indemnity was granted, no attempt will be made to isolate those which involved a broader contractual relationship.

30. See notes 31-39 infra.

31. E.g., Smith v. Foran, 43 Conn. 244 (1875); Skala v. Lehon, 343 Ill. 602, 175 N.E. 832 (1931); Weidert v. Monahan Post Legionnaire Club, 51 N.W.2d 400, 404 (lowa 1952).

For criticism of imdemnity in such situations see Fleming, The Role of Negligence in Modern Tort Law, 53 VA. L. Rev. 815,834 (1967).

32. E.g., George A. Fuller Co. v. Otis Elevator Co., 245 U.S. 489 (1918); Lawrence v. Great Northern Ry., 98 F. Supp. 746 (D. Minn. 1951).

33. E.g., Traub v. Dinzler, 309 N.Y. 395, 131 N.E.2d 564 (1955); CAL. Venicle CODE $\$ 17153$ (West Supp. 1969) (subrogation). See Davis, supra note 7, at 521.

34. See, e.g., 3 FrUMER \& FRIEDMAN, supra note 2, at $\S 44.02[3]$ and cases cited therein for illustrative indemnity situations.

35. E.g., Cushing v. Rodman, 82 F.2d 864 (D.C. Cir. 1936); Roberts v. Richland Mfg. Co., 260 F. Supp. 274 (W.D. Mich. 1966); Martin v. Great Atl. \& Pac. Tea Co., 301 Ky. 429, 192 S.W.2d 201 (1946); Schwartz v. Macrose Lumber \& Trim Co., 50 Misc. 2d 1055, 272 N.Y.S.2d 227 (1966).

36. Kroger Co. v. Bowman, 411 S.w.2d 339 (Ky. Ct. App. 1967); Rodgers v. Karem, 405 S.W.2d 741 (Ky. Ct. App. 1966).

37. See cases cited notes 35 and 36 supra; Restatement of Restitution $\$$ 93(1) (1937): "Where a person has supplied to another a chattel which because of the supplier's negligence or other fault is dangerously defective for the use for which it is supplied and both have become liable in tort to a third person injured by such use, the supplier is under a duty to indemnify the other for expenditures properly made in discharge of the claim of the third person, if the other used or disposed of the chattel in reliance upon the supplier's care and if, as between the two, such reliance was justifiable."

38. An initial carrier, held strictly liable to the shipper for the loss of goods shipped, has been allowed indemnity from either a supplier of defective equipment which caused the damage to the goods, see Bethlehem Shipbldg. Corp. v. Joseph Gutradt Co., 10 F.2d 769 (9th Cir. 1926), or a connecting carrier whose negligence actually caused the loss, e.g. Orlove v. Philippine Airlines, 257 F.2d 384 (2d Cir. 1958).

39. E.g., Oats v. Dublin Nat. Bank, 127 Tex. 2, 90 S.W.2d 824 (1936); Hoggan v. 


\section{Liability with Negligible Fault}

The second category involves defendants found liable despite the fact that their own fault was negligible. These situations generally involve a failure to discover or remedy a dangerous condition created by someone else. The seeker of indemnity has been held liable for his "nondelegable duty" toward the person injured, even though practically speaking it would have been impossible for him to have inspected thoroughly enough to have removed the danger created by the indemnitor's action.

For example, municipalities are held to have a nondelegable duty to maintain their streets and sidewalks in a safe condition. If a third person, such as an abutting landowner, creates a hazardous condition on a street or sidewalk which leads to injury and a recovery against the municipality, the city is entitled to indemnity from the creator of the hazard. ${ }^{40}$ Owners and occupiers have a similar duty to inspect their premises in order to assure that the premises are safe for their invitees." This is a very heavy burden on the occupier, so if he can show that a third person's negligence created the unsafe condition, he can be granted indemnity from that person..$^{12}$

\section{Liability with Lesser Fault}

In the two previous groups of cases, the person given indemnity was either totally or virtually free of fault. These are the clear cases where almost all jurisdictions agree indemnity is proper. Some jurisdictions have gone further: They permit a tortfeasor who is

Cahoon, 26 Utah 444, 73 P. 512 (1903) (agent induced to convert another's goods); W. Prosser, supra note 2, at 279-80; Restatement, Restitution $\$ 90$ (1937); Davis, supra note 7, at 528; Leflar, supra note 5, at 150-51.

40. E.g., Des Moines v. Barnes, 238 Iowa 1192, 30 N.W.2d 170 (1947) (icy condition of sidewalk caused by landowner's downspout); Lowell v. Boston \& Lowell R.R., 40 Mass. (23 Pick.) 24 (1839) (the defendant railroad failed properly to barricade an excavation it made in the street); Kilroy v. St. Louis, 242 Mo. 79, 145 S.W. 769 (1912) (abutting landowner negligently maintained a sidewalk grating).

41. See, e.g., W. Prosser, supra note 2, at 402.

42. E.g., Preferred Acc. Ins. Co. v. Musante, Berman \& Steinberg Co., 133 Conn. 536, 52 A.2d 862 (1947); Brown Hotel Co. v. Pittsburg Fuel Co., 311 Ky. 396, 224 S.W.2d 165 (1949) (hotel held liable to pedestrian who fell through coal hole entitled to recover from the fucl company whose employee negligently replaced the lid); Scott v. Curtis, 195 N.Y. 424, 88 N.E. 794 (1909) (coal hauler left cover off of sidewalk coal holc.)

Similarly, an employer who is held by an injured employee for a failure to provide a safe place to work is allowed indemnity from the creator of the danger. E.g.. Appalachian Corp. v. Brookiyn Cooperage Co., 151 La. 41, 91 So. 539 (1922); Busch \& Latta Painting Co. v. Woermann Constr. Co., 310 Mo. 419, 276 S.W. 614 (1925). And two surgeons held liable for a sponge left in a patient were found to have stated a cause of action for indemnity from the hospital and nurses. Melburn v. Walker. 279 F. Supp. 740 (D. Ncb. 1968). 
substantially at fault, but who can show that his negligence was less than that of his co-tortfeasor(s), to shift the entire loss to the person more negligent. ${ }^{33}$ Such a determination involves a balancing and comparing of degrees of culpability.

The previous groups of cases also involved a comparison of degree of fault but only in the sense that indemnity was permitted those who were entirely free of active fault or who were merely negligent in failing to discover the negligent act of someone else. The comparison test in this third group of cases is significantly different: A person who is quite clearly at fault is permitted to avoid any loss at all if he is fortunate enough to find someone who was even more culpable. This doctrine probably developed in response to the rule barring contribution:4 If indemnity were denied in such cases, the less negligent party might be stuck with the entire loss. In this all-ornothing setting, courts sometimes decided that it would be more equitable to place the entire loss on the more negligent party rather than leave the loss entirely on the slightly less negligent party. ${ }^{45}$

The most significant of these cases is United Air Lines, Incorporated $v$. Wiener, ${ }^{46}$ which involved the collision in Nevada of an airliner and a military jet on a training maneuver. The Ninth Circuit

43. E.g.. Banks v. Central Hudson Gas \& Elec. Corp., 224 F.2d 631, 634 (2d Cir. 1955) ("active"-"passive" test essentially a question of comparative negligence of the two actors to be decided by a jury); Slattery v. Marra Bros., 186 F.2d 134, 139 (2d Cir. 1951) (dictum) ("[T]he inquiry is always whether the difference in the gravity of the faults of the participants is so great as to throw the whole loss upon one"'); Gulf, M. \& O.R.R. v. Arthur Dixon Transfer Co., 343 111. App. 148, 98 N.E.2d 783 (195I) (plaintiff railroad allowed to recover over from defendant loss caused by employee being crushed between a box car and defendant's negligently parked trucks).

"Very slight differences in the duty owned or the culpability of persons failing to perform that duty' have supplied the basis for an allowance of indemnity on the theory that the third party plaintiff was guilty of only 'passive' negligence while the third party defendant was guilty of 'active' negligence." Jones, Contribution Among Tortfeasors, I1 U. FLA. L. REv. 175, 195 (1958), citing N.Y. LAw Revision CoMm': REP. 28 (1952).

44. See Davis, supra note 7, at 553; Jones, Contribution Among TortJeasors, supra note 43, at 195.

45. See note 43 supra; Orlove v. Philippine Air Lines, 257 F.2d 384 (2d Cir. 1958) (airline held for failure to get valuation of goods shipped allowed to recover from airline that actually lost them); Kantleherer v. United States, 279 F. Supp. 122, 128-29 (E.D.N.Y. 1967) (" . . . a right of indemnity exists where the parties are not equally culpable, and has the effect of shifting the entire loss to the more culpable wrongdoer'); Austin Elec. Ry. v. Faust, 63 Tex. App. 91, I33 S.IV. 449 (1910).

It has been suggested that a person guilty of ordinary negligence is entitled to indemnity from one grossly negligent. Keeton, Contribution and Indenmity Among Torteasors, 27 lNs. Counsel J. 630, 631 (1960). The cases have not adopted this position, see Jacobs v. Gen. Accident, Fire * Life Assurance Corp., 14 Wis. 2d 1, 109 N.W.2d 462, $465-66$ (1961), except to deny contribution to an intentional wrongdoer against a negligent one, see Hardware Mut. Cas. Co. v. Danberry, 48 N.W.2d 567 (Minn. 195I). 
set forth the district court's findings of four specific acts of negligence which United had committed and thirteen specific acts of negligence by the Government. The court then weighed and compared degrees of fault and granted indemnity to United, concluding:

In view of the disparity of duties, the clear disparity of culpability, the likely operation of the last clear chance doctrine and all the surrounding circumstances, the findings that United and the government were in pari delicto are clearly erroneous and wc hold that there is such difference in the contrasted character of fault as to warrant indemnity in favor of United in the nongovernment employee cases. ${ }^{17}$

Wiener is, then, the clearest statement that a tortfeasor substantially at fault may be ultimately let off completely if he is able to point to a co-tortfeasor who is more culpable. While Wiener is one case which cannot be explained on the grounds that contribution was either not available or restricted by a requirement of a joint judgment, ${ }^{48}$ the theories upon which the decision was based were formulated at a time when contribution was generally unavailable and a judge was left with an all-or-nothing choice. ${ }^{49}$

Thus, in America indemnity has been made available in a number of situations. The courts, in granting or denying it, have frequently resorted to one of three verbal formulas. Indemnity is

46. 335 F.2d 379 (9th Cir.), cert. dismissed, 379 U.S. 951 (1964).

47. Id. at 402 .

48. The trial judge had allowed contribution, concluding that Nevada would permit contribution by judicial decision. Wiener v. United Air Lines, 216 F. Supp. 701,708 (S.D. Cal. 1962).

49. Specifically, the court relied heavily on Leflar's theory of last clear chance and Davis' theory of disparity of duties. Leflar urged that such cases generally involve the normal application of the "last clear chance" doctrine: The indemnitor is held because he had the last clear chance to avoid injury. Leflar, supra note 5, at 151-54. The theory developed out of a New Hampshire case expressly holding on the grounds of the last clear chance doctrine. Nashua lron \& Steel Co. v. Worcester \& N.R.R., 62 N.H. 159 (1882). Leflar wrote in 1932, when contribution was virtually unavailable and cited cases from jurisdictions where it was not available.

Davis theorized that indemnity is warranted where one tortfeasor owes a higher duty of care to the injured party than does the indemnitor. Davis, supra note 7, at 546-53. He took great pains, however, to emphasize that his idea of discrepancies in duty should not be used to extend the use of indemnity where contribution, if allowed, would be more appropriate, saying: "Indemnity should be confined to a rather narrow field. It should be kept closely within the bounds of those cases where the disparity of the duties owed to the injured person by the two negligent tortfeasors is such that the liability of the one recciving indemnity is without the indemnitee's personal fault, or closel. approximates absolute liability. . . Otherwise the temptation is to shift the entire responsibility for a tort loss to the one who seems the more guilty. The result is a distorted law of indemnity, with indemnity being allowed in some cases where contribution would be more proper." Id. at $552-53$ (emphasis added). 
granted because the negligence of one party is "active" in contrast to the "passive" nature of the indemnitee's negligence;"50 the liability of one may be deemed "secondary," and he is entitled to recover from the party with "primary" responsibility;" or indemnity may be granted where the parties are not "in pari delicto." ${ }_{52}$ The consensus of the commentators ${ }^{53}$ is that these are really meaningless verbal labels pinned on after a conclusion has been reached; this is particularly true when there is substantial fault on both sides. It would be more useful if the courts would explicitly consider the cases' factual situations in terms of the suggested fault categories rather than their conclusory verbal formulas.

\section{B. Decline of the Rule Against Contribution}

In most instances it was not until after the indemnity exceptions to the common law rule had been carved out that American jurisdictions began to allow contribution among tortfeasors. In the last quarter century this movement has gained tremendous momentum. By 1968 a majority of the states ${ }^{54}$ and several federal courts $^{55}$ had abrogated the rule against contribution, either by statute ${ }^{56}$ or by judicial action ${ }^{57}$ - a dramatic change from 1941 when the over-

50. E.g., Banks v. Central Hudson Gas \& Elec. Corp., 224 F.2d 631, 635 (2d Cir. 1955);

Seiden v. Savings \& Loan Ass'n, 10 Misc. 2d 720, 172 N.Y.S.2d 403 (N.Y. City. Ct. 1958).

5l. E.g., American Dist. Tel. Co. v. Kittleson, 179 F.2d 946 (8th Cir. 1950); Fidelity \& Cas. Co. v. Federal Express, 1nc., 99 F.2d 681 (6th Cir. 1938); Brooklyn v. Brooklyn City R.R., 47 N.Y. 475,487 (1872).

52. I:.g., Washington Gas Light Co. v. District of Columbia, 161 U.S. 316, 327 (1896); Middlesboro Home Tel. Co. v. Louisville \& N.R.R., 214 Ky. 822, 284 S.W. 104 (1926).

53. See, e.g., Leflar supra note 5, at 153-56; Davis, supra note 7, at 539-44.

54. See notes 56 and 57 injra.

55. See note 57 injra.

56. ARK. Stat. ANN. $\$ \$ 34-1001$ to -09 (1962); Ca1.. Civ. Pro. Cods $\$ \$ 875-80$ (West Supp. 1969); Dit.. CoDE ANN. tit. 10, $\$ \$ 6301-08$ (1953); GA. CODE ANN. $\$ \$ 105-2011$ to -12 (1968) (joint trespassers only); Hawall Rıv. Laws $\$ 246-11$ (1955); Ky. Rev. Stat. $\$ 412.030$ (1962) (if the negligence involves no moral turpitude); LA. CIv. CODE ANN. art. 2103 (Supp. 1969) (amended 1960 to allow impleader of co-tortfeasor); MD. ANN. CoDE art. $50 \$ \$ 16-24$ (1968); MASS. Gen. Laws ANN. ch. 231 B \$\$ 1-4 (Supp. 1969); Mich. CoMp. Laws ANN. § 600.2925 (1968); Miss. CodE ANN. \$ 335.5 (1957); Mo. STAT. ANN. $\$ 537.060$ (1953), N.J. Stat. ANN. \$§ 2A:53A (1)-(5) (1952); N.M. STAT. ANN. \$§ 24-1-11 to-18 (1953); N.Y. Civ. PRAC. 7B \$ 1401 (McKinney 1962); N.C. Gen. Stat. \$\$ 1B-1 to -8 (Supp. 1967); N.D. Cent. Code ANN. $\$ \$ 32-38-01$ to -04 (1960); PA. Stat. ANn. tit. 12, \$\$ 2082-89 (1967); R.1. Gen. LAwS $\$ \$ 10-6-1$ to -11 (1956); S.D. CODE $\$ \$ 33.04 A 01-33.04 A 10$ (Supp. 1952); TENN. Code ANN. $\$ \$ 23-3101$ to -06 (Supp. 1968); TEX. Civ. Stat. art. 2212 (1964); VA. Code ANN. $\$ 8-627$ (1957) (if negligence involves no moral turpitude); W. VA. CODE $\S 55-7-13$ (1966).

57. Knell v. Feltman, I74 F.2d 662 (D.C. Cir, 1949); Best v. Yerkes, 247 Iowa 800, 77 N.W.2d 23 (1956); Hobbs v. Hurley, 117 Me. 449, 104 A. 815 (1918); Lloyds v. Smith, 166 Minn. 388, 208 N.W. 13 (1926); Nevada, Wiener v. United Airlines, Inc,, 216 F. Supp. 701, $707-$ 08 (S.D. Cal.), rev'd on other grounds. 335 F.2d 379 (9th Cir. 1964); Goldman v. Mitchell- 
whelming majority of our courts refused to permit contribution..$^{58}$

This was not achieved without major controversy. ${ }^{\text {gl }}$ Professor James vigorously challenged the fundamental basis of contribution as being a fine adjustment of an outmoded fault principle at the expense of more important tort policy goals. ${ }^{60}$ Specifically, James saw contribution as a threat to the paramount tort goals of adequate compensation for the victim and effective distribution of the loss over a large segment of society. ${ }^{61}$

Contribution, he argued, tends to disfavor plaintiffs. ${ }^{62}$ First, this is because most contribution schemes provide that a covenant not to sue given by the plaintiff cannot protect one potential defendant, who might otherwise be willing to settle, from a subsequent claim for contribution. ${ }^{63}$ Second, a plaintiff is seriously disadvantaged in pretrial bargaining because he is unable to play one defendant off against the other ${ }^{64}$ Finally, if impleader of a co-tortfeasor is permitted, the plaintiff loses his leverage for choosing his defendant. ${ }^{65}$

Contribution allegedly favors "the large and wealthy at the expense of the relatively poor and weak," ${ }_{66}$ thereby hampering effective accident loss distribution. Colltribution is said to almost always involve a good loss distributor, either an insurance company or self-insurer, recovering from a poorer loss distributor whom the plaintiff did not sue because of his lack of ability to pay ${ }^{67}$ Thus it is claimed that contribution is a serious impediment to effective loss spreading. These propositions represent a serious attack which requires consideration.

If Professor James' assumptions are granted, it is difficult to dispute his thesis. However, as he noted himself, ${ }^{68}$ his propositions

Fletcher Co., $292 \mathrm{~Pa}$. 354, 141 A. 231 (1928) (later adopted statute, see note 55 supra); Davis v. Broad St. Garage, 191 Tenn. 320, 232 S.W.2d 355 (1950); (where not willful tort or immoral act) (apparent confusion of indemnity and contribution concepts clarified by statutc, see note 55 supra); Virgin Islands, Gomes v. Brodhurst, 394 F.2d 465, 467 (3d Cir. 1967); Bielski v. Schulze, 16 Wis. 2d I, 114 N.W.2d 105 (1962).

58. W. Prosser, HaNDBoOK OF THE LAW OF TORTs 117 (1941).

59. See James, Contribution Among Joint Tortfeasors: A Pragmatic Criticism, 54 HaRv. L. REV. 1156 (1941); Gregory, Contribution Among Joint Tortfeasors: A Defense, id. at 1170; James, Replication, id. at 1178; Gregory, Rejoinder, id. at 1184.

60. James, Contribution Among Joint Tortfeasors: A Pragmatic Criticism, 54 Harv. L. REY. 1156 (1941).

61. Id.

62. Id. at 1160.

63. Id.

64. Id. at $1160-61$.

65. Id. at 1164 .

66. Id. at 1165 .

67. Id, at 1165-67.

68. Id. at 1159 . 
cannot be proven by the decided cases; they remain speculations based on questionable assumptions.

The charge that contribution will hamper a plaintiff's recovery is at least doubtful. In the situation which James contends will be most common, that of an insurance company or self-insurer seeking contribution from an impoverished, uninsured tortfeasor, ${ }^{69}$ contribution is unlikely to be a factor in settling with the plaintiff. ${ }^{70}$ if the defendant insurance company settles with the plaintiff, it will have very little reason to fear having to pay contribution to a subsequent judgment against the uninsured co-tortfeasor. A plaintiff would have no reason to take the trouble of subsequently suing a defendant who was not able to pay. In addition, juries, as a practical matter, are unlikely to inflict upon an impoverished, uninsured defendant as large a judgment as they would upon an insurance company.

In the case where two or more insureds are involved, free contribution should promote out-of-court settlement. Where a right to contribution exists without the requirement of a joint judgment, ${ }^{71}$ an insurance company which settles knows it can recover a share from the other defendant's insurance company. If there is no right to contribution, or if a joint judgment is required, an insurance company will be more reluctant to settle, knowing that it will be unable to recover from the other tortfeasor a part of the amount paid out. The Supreme Court of California found this to have been the conclusion of the legislature when it removed the joint judgment requirement of the California contribution laws in order to facilitate the settlement of multiple claims arising from the Baldwin Hills dam disaster. ${ }^{72}$

The assertion that contribution will result in a good loss distributor shifting the burden to a poor loss distributor is also doubtful. In some cases, particularly those involving products liability, plaintiffs often sue the poorer loss distributor-such as a local retailer-because he is the most identifiable and easily reached defendant. The merchant then seeks contribution or indemnity from a better loss distributor, the manufacturer. In probably the most frequent cases of multiple fault, automobile cases, if both drivers are insured-which does not seem unlikely-nothing is lost by allowing contribution because both are equally good loss distributors.

69. Id. at 1165-67.

70. The insurance company may have other strong reasons for reluctance to settle, the most obvious one being a desire to use the money involved for investment over the long period of time necessary to reach a conclusion by litigation.

71. See notes 83-86 infra and accompanying text.

72. See Los Angeles v. Standard Oil Co., 262 A.C.A. 144, 150, 68 Cal. Rptr. 512, 515 (1968). 
Professor James has raised some important questions, but his conclusions are highly speculative. It is impossible to know precisely what effect contribution has on loss distribution. ${ }^{73}$ To the extent that Professor James' assumptions are correct, and contribution retards the dominant tort goals of victim compensation and loss spreading, it is clear that indemnity is even more destructive of these goals:

Viewed in terms of loss distribution, indemnity raises with even greater force the arguments that would deny contribution in collision cases, for indemnity enables a superior loss distributor to shift not just a contributory share but all damages to a tortfeasor who cannot pass on his losses. ${ }^{74}$

Yet this is precisely what an absolute rule against contribution or a joint judgment restriction tends to produce under our tort system. The widespread adoption of contribution, in the face of James' challenge, ${ }^{75}$ represents the triumph of the view that it is unfair to permit a plaintiff to saddle one of several wrongdoers while others equally culpable go scot free. ${ }^{76}$

\section{III}

\section{CALIFORNIA CONTRIBUTION AND INDEMNITY PRIOR TO RYAN}

The development of contribution and indemnity in California was unusual in two respects. First, they were very late in coming; the common law rule barring both contribution and indemnity among tortfeasors persisted - with a few indemnity exceptions ${ }^{77}$ - until $19588^{78}$

73. Some commentators have suggested a statistical study to determine what really happens in terms of loss shifting. See Meriam and Thornton, Indemnity between Tort-jeasors: An Evolving Doctrine in the New York Court of Appeals, 25 N.Y.U.L. Rev. 845, 860-61 (1950) (discussing such a study with respect specifically to indemnity). However, such a study may well be impractical. It could be very difficult to get information which is not in the interest of the insurance companies to divulge.

74. Comment, Adjusting Losses Among Joint Tortfeasors in Vehicular Collision Cases, 68 YALE L.J. 964, 977 (1959).

75. Professor James has his own explanation: "The fact that the Uniform Contribution Among Tortfeasors Act has made the headway it has is indeed a tribute to completely disinterested (and I believe completely unrealistic) law reforming zeal." James, Indemmity: Subrogation, and Contribution and the Efficient Distribution of Accident Losses, 2I NACCA Law J. 360, 368 (1958).

76. W. Prosser, supra note 2, at 275.

77. Indemnity has long been allowed by express contract. CAL. CIv. CODE $§ 2772$ (West 1966) (enacted 1872); Markley v. Beagle, 66 Cal. 2d 951, 429 P.2d 129, 59 Cal. Rptr. 809 (1967).

An employer held vicariously responsible for the negligence of his employee was granted indemnity in the absence of an express indemnity agreement as early as 1908. Bradley $v$. Rosenthal, 154 Cal. 420,97 P. 875 (1908). In a few other isolated cases what amounted to 
Second, whereas in other jurisdictions the indemnity rights normally antedated the emergence of contribution, in California the two doctrines developed almost simultaneously.

\section{A. The California Contribution Statutes}

The California contribution statutes ${ }^{79}$ which have been in operation since $1958,{ }^{80}$ provide a right to contribution among joint tortfeasors against whom a joint judgment has been rendered. ${ }^{81}$ The provisions differ from the 1939 Uniform Contribution Among Tortfeasors Act in two critical respects.

First, the California scheme, unlike the Uniform Act, ${ }^{82}$ does not recognize a right to contribution unless a joint judgment has been rendered ${ }^{83}$ The undesirability of the California provision has long been evident since it results in making the right to contribution dependent upon the plaintiff's course of action. ${ }^{84}$ This is so because the California courts have construed the provision to prohibit a crosscomplaint for contribution, ${ }^{85}$ on the theory that the right does not accrue until one of the joint tortfeasors has paid more than his pro rata share of a joint judgment. ${ }^{86}$ This reasoning is anything but compelling in view of the permissibility in California of cross-complaints for

indemnity was granted without calling it indemnity or discussing the doctrine. Merchant Shippers Ass'n v. Kellog Express and Draying Co., 28 Cal. 2d 594, 170 P.2d 923 (1946) (granting recovery over to a forwarder shipper from a common carrier).

78. E.g., San Francisco v. Ho Sing, 51 Cal. 2d 127, 137, 330 P.2d 802, 808 (1958); Alisal Sanitary Dist. v. Kennedy, 180 Cal. App. 2d 69, 74, 4 Cal. Rptr. 379, 383 (1960); Molinari, supra note 12 , at 159 .

79. Cal. Civ. Pro. Code $\$ \$ 875-80$ (West Supp. 1969).

80. Ch. $1700, \S 1,[1957]$ Cal. Stats. 3076.

81. Cal. Civ. Pro. Code $\$ 875$ (West Supp. 1969).

82. UNiform CONTRIBUTION AMONG TORTFEASORS ACT $\$ 1$ (1939 version).

83. Cal. Civ. Pro. Code $\S 875$ (a) (West Supp. 1969).

84. Note, Contribution Between Joint Tortfeasors: $A$ Legislative Proposal, 24 CALIF. L. Rev. 546, 552 (1936). Moreover, the joint judgment requirement was "responsible for the complete failure" of the similar New York statute. Gregory, Contribution Aniong Tortfeasors: A Uniform Practice, 1938 WIS. L. REv. 365, 369.

85. See Thornton v. Luce, 209 Cal. App. 2d 542, 551-52, 26 Cal. Rptr. 393, 398 (1962) (rejecting objection to dismissal of a codefendant from the action); American Can Co. v. San Francisco, 202 Cal. App. 2d 520, 523, 21 Cal. Rptr. 33, 34 (1962) (dictum) ("[A]ppellants are clearly not seeking contribution pursuant to Code of Civil Procedure section 875, since no money judgment has been rendered jointly against appellants and respondent'); $c f$., August v. Bean, 56 Cal. 2d 270, 272, 363 P.2d 873, 874, 14 Cal. Rptr. 641, 642 (1961).

In so construing the statute California followed New York's earlier example. Fox v. Western N.Y. Motor Lines, Inc., 257 N.Y. 305, 178 N.E. 289 (1931).

86. See Thornton v. Luce, 209 Cal. App. 2d 542, 55i-52, 26 Cal. Rptr. 393, 398 (1962); American Can Co. v. San Francisco, 202 Cal. App. 2d 520, 523, 21 Cal. Rptr. 33, 34 (1962) (dictum); cf. August v. Bean, 56 Cal. 2d 270, 272, 363 P.2d 873, 874, 14 Cal. Rptr. 641, 642 (196I). 
declaratory judgment conforming a right to indemnity. ${ }^{87}$ In order to implead a co-tortfeasor whom the plaintiff has chosen not to join, a California defendant must fashion his cross-claim in indemnity rather than contribution.

Second, the 1939 Uniform Act contained provisions for thirdparty practice permitting questions of contribution to be decided along with the main tort action..$^{8}$ Such provisions were omitted from the California act. ${ }^{89}$

The result of these two major defects is that California contribution remedies remain very restricted. The plaintiff retains the power to decide who shall bear the loss. The problem of collusion between the plaintiff and one party, and the extreme unfairness which can result from the plaintiff's whim or spite in holding only one of the wrongdoers, still remain. Even where a codefendant who would be liable for contribution is exonerated in the original action because of an admittedly erroneous instruction, the defendant has no standing to appeal because his right to contribution requires the rendition of a joint judgment. ${ }^{90}$ Settlements before trial are discouraged because without a joint judgment the payor cannot enforce contribution." This rule's requirement of a separate action for contribution results in substantial duplication and wasted effort. ${ }^{22}$ Finally, as long as the contribution scheme remains inadequate there will be pressure to use the all-ornothing approach of indemnity.93 This produces both a less equitable allocation of the loss than would contributory sharing and, to the extent James' assumptions are valid, ${ }^{94}$ an even more serious impediment to the

87. See Roylance v. Doelger, 57 Cal. 2d 255, 258-59, 368 P.2d 535, 536-37, 19 Cal. Rptr. 7,9 (1962); Lewis Ave. Parent Teachers' Ass'n v. Hussey, 250 Cal. App. 2d 232, 235, 58 Cal. Rptr. 499, 501 (1967).

88. Uniform Contribution Among Tortfeasors ACt $\$ 7$ (1939 version).

89. Cal. Civ. Pro. Code $\$ \S 875-80$ (West. Supp. 1969).

90. Guy F. Atkinson Co. v. Consani, 223 Cal. App. 2d 342, 344, 35 Cal. Rptr. 750, 751 (1963).

91. Los Angeles v. Standard Oil., 262 A.C.A. 144, 150, 68 Cal. Rptr. 512, 515 (1968); see Guy F. Atkinson Co. v. Consani, 223 Cal. App. 2d 342, 345-46, 35 Cal. Rptr. 750, 751 (1963).

92. E.g., Gregory, Procedural Aspects of Securing Tort Contribution in the Injured Plaintiff"s Action, 47 HARv. L. REv. 209, 210-11 (1933): "The altcrnative of a scparate action over is simpler, but has the compensating disadvantages of requiring two actions and usually two jury trials where one would have sufficed. This, in turn, delays the recovery of contribution. increases the work of the courts, multiplies the cost of litigation for the commonwcalth and the parties to the contribution issue, and creates the risk that the claimant will lose testimony by death, removal, or lapse of memory on the part of the witnesses."

This weakness was emphasized at the time the California statute was adopted. Note, Joint Tortfeasors: Legislative Changes in the Rules Regarding Releases and Contribution, 9 Hastings L.J. 180, 188 (1958).

93. See notes 44 \& 45 supra and accompanying text.

94. See notes 6I-67 supra and accompanying text. 
tort goals of loss spreading and victim compensation..$^{95}$ The argument that a joint judgment requirement is necessary to prevent inconsistent results could easily be answered with an effective contribution right which would not only avoid inconsistent judgments but also apportion the loss equitably. ${ }^{96}$

\section{B. Indemnity in California Prior to Ryan}

The doctrines of implied contractual indemnity ${ }^{97}$ and noncontractual indemnity ${ }^{98}$ were first established in California in 1958, the same year as the contribution statutes. In addition to this unusual contemporaneous birth of contribution and indemnity rights, the development of indemnity in California differed from that characteristic of other jurisdictions in two other significant respects. First, indemnity has never been granted in cases falling within the category of "liability with lesser fault," contribution has always been an available alternative. Second, the practice of balancing and comparing degrees of fault through the use of the "active-passive" dichotomy was rejected in California. ${ }^{100}$ The terms "active-passive" were sometimes used but in a very limited and quite different context. ${ }^{101}$

The differences from developments typical of other jurisdictions are crucial to an understanding of Ryan's distinctive California context. Like other jurisdictions, ${ }^{102}$ California permitted a concurrent tortfeasor to recover indemnity when he was not personally at fault. Within the category of "liability without fault"103 the following have been given recovery from the negligent actor: An employer held liable under respondeat superior, ${ }^{104}$ an automobile owner accountable for a

95. See note 74 supra and accompanying text.

96. See text accompanying notes 138-41 infra.

97. San Francisco Unified School Dist. v. California Bldg. Maint. Co., 162 Cal. App. 2d 434, 328 P.2d 785 (1958).

98. San Francisco v. Ho Sing, 51 Cal. 2d 127, 330 P.2d 802 (1958).

99. Compare note 43 supra with notes 113-16 infra.

100. Compare note 43 supra with note 125 infra.

101. See notes 121-25 infra and accompanying text.

102. See notes $30-42$ supra and accompanying text.

103. See notes $30-39$ supra and accompanying text.

104. Continental Cas. Co. v. Phoenix Constr. Co., 46 Cal. 2d 423, 428, 296 P.2d 801, 804 (1956): Popejoy v. Hannon, 37 Cal. 2d 159, 173, 23I P.2d 484, 492 (195I); Bradley v. Rosenthal, 154 Cal. 420, 97 P. 875 (1908); Herrero v. Atkinson, 227 Cal. App. 2d 69, 77, 38 Cal. Rptr. 490, 494-95 (1964) (dictum); Walsh v. Hooker \& Fay, 212 Cal. App. 2d 450, 462, 28 Cal. Rptr. 16, 24 (1963).

However, the imputed negligence of the employer is not the equivalent of "passive negligence." An employer can be barred from collecting indemnity from a third party because of "active negligence" of his agent which is imputed to him. Baldwin Contracting Co. v. 
driver's negligence, ${ }^{105}$ a seller ${ }^{106}$ or user ${ }^{107}$ of a product which causes injury because defective when supplied to the seller or user, a party held because of the negligence of his subcontractor, ${ }^{108}$ and an original tortfeasor held for subsequent negligent treatment of the plaintiff by

Winston Steel Works, Inc, 236 Cal. App. 2d 565, 572, 46 Cal. Rptr. 421, 425 (1965); Horn \& Barker, Inc. v. Macco Corp., 228 Cal. App. 2d 96, 103, 106, 39 Cal. Rptr. 320, 324, 326 (1964).

An employer may be denied recovery from his negligent employee under CAL. LABOR CODE $\S 3864$ (West Supp. 1969) if that employee is also the employer of the injured party and covered by workman's compensation. In a recent case the San Francisco Examiner was held under the doctrine of respondeat superior for the negligence of its agent and the resultant injury to the delivery boy employed by the agent, but the Examiner was barred by CAL. LABOR CODE § 3864 from recovering indemnity from the agent. San Francisco Examiner Division, Hearst Publishing Co. v. Sweat, 248 Cal. App. 2d 493, 56 Cai. Rptr. 711 (1967).

105. An automobile owner can be held liable for injury caused by a driver who is using the car with the owner's permission. CAL. VeHICLE CODE $\$ \S 17150-52$ (West 1960). The owner is then permitted to recover from the driver the total amount of any judgment recovered against him because of the driver's negligence imputed to him. Whether labeled a right to subrogation or contribution, it in fact amounts to a right of indemnity. CAL. VEHICLE CODE $\$ \$ 17153$ (West 1960) (subrogation); Skeen v. Payne, 183 Cal. App. 2d 605, 607, 7 Cal. Rptr. 185, 187 (1960) (dictum); Broome v. Kern Valley Packing Co., 6 Cal. App. 2d 256, 262, 44 P.2d 430, 433 (1935) (contribution).

106. Klein v. Asgrow Seed Co., 246 Cal. App. 2d 87, 54 Cal. Rptr. 609 (1966). But in order for the seller to recover indemnity from his supplier he must give notice to the supplier of the breach of warranty. Faucette v. Lucky Stores, Inc., 219 Cal. App. 2d 196, 33 Cal. Rptr. 215 (1963).

107. In B.F.G. Builders v. Weisner \& Coover Co. 206 Cal. App. 2d 752, 23 Cal. Rptr. 815 (1962), an employee of a roofing subcontractor sued the builder for personal injuries caused by the collapse of the roof, allegedly because of defective sheathing. The court held that the builder's cross-complaint for indemnity against the supplier of the allegedly defective sheathing was not subject to a motion to strike.

108. The first real breakthrough allowing implied indemnity among tortfeasors in California occurred in 1958 with the decision in San Francisco Unified School District v. California Building Maintenance Co., 162 Cal. App. 2d 434, 328 P.2d 785 (1958). The school district had been held for injuries to defendant's employee while he was washing windows in the school and sought indemnity from the maintenance company. The court held that the window washing contract carried an implied agreement to indemnify the school district for injuries owing to a breach of the agreement.

In so holding, the court relied heavily on the rationale of two United States Supreme Court decisions. In both cases a shipowner was allowed to claim indemnity from a stevedoring company whose employee had been injured because of the unsafe methods used in unloading the cargo. Although no express indemnity agreement was present, the general contract was held to imply an obligation to perform the stevedoring safely and to indemnify the ship owner for injuries arising from stevedoring misconduct. Weyerhaueser S.S. Co. v. Nacirema Operating Co., 355 U.S. 563, 569 (1958); Ryan Stevedoring Co. v. Pan-Atlantic S.S. Corp., 350 U.S. 124, 133 (1955). The Court in Weyerhaueser did note, however, that the shipowner was only "entitled to indemnity absent conduct on its part sufficient to preclude recovery." 355 U.S. at 567.

Since the groundbreaking in San Francisco Unified School District, the California courts have permitted indemnity to be implied from a contractual relationship in a wide range of cases as long as the person seeking indemnity had not, through his own "active negligence," contributed to the injury. Muth v. Urricelqui, 25I Cal. App. 2d 901, 60 Cal. Rptr. 166 (1967) (action by general building contractors seeking indemnification from subcontractors who 
doctors and hospital. ${ }^{109}$ In the "negligence with negligible fault" category, a municipality held for its nondelegable duty to maintain safe streets, ${ }^{110}$ an employer liable for failure to discover a dangerous condition, ${ }^{111}$ and individuals held liable as owners and occupiers, ${ }^{112}$ have been given indemnity from the creators of the hazards.

Unlike some jurisdictions, however, California refused to grant indemnity in situations where both parties were substantially at fault. Within the category of "liability with lesser fault," indemnity had been denied in cases of concurrent negligence, ${ }^{113}$ negligent failure to

allegedly performed their work in a negligent manner proximately causing damages to a house by reason of landslide and subsidence); Aerojet Gen. Corp. v. D. Zelinski \& Sons, 249 Cal. App. 2d 604, 608, 57 Cal. Rptr. 701, 703 (1967) (defendant contracted to paint two liquid fuel storage tanks for plaintiff; explosion lead to death of two of defendant's employees); Ralke Co. $v$. Esquire Bldg. Maint. Co., 246 Cal. App. 2d 14l, 54 Cal. Rptr. 556 (1966) (defendant engaged as independent contractor to do maintenance work; his employee left a slick spot which caused injury to one of plaintiff's patrons); Alisal Sanitary Dist. v. Kennedy, 180 Cal. App. 2d 69, 4 Cal. Rptr. 379 (1960) (defendants were engineers who negligently designed and supervised construction of 14 manholes in a sewage line; the river rose and sewage came out of manhole number 12 onto a celery field which was destroyed); De La Forest v. Yandle, 171 Cal. App. 2d $59,62,340$ P.2d 52, 54 (1959) (overruled the sustaining of defendant's demurrer to an indemnity claim, holding the owner of a truck repair shop, who had sublet the axle welding to the defendant, had stated a cause of action for indemnity against the negligent axle welder).

The question of the indemnitee's "active negligence" has been held to be a question of fact for jury determination. Muth v. Urricelqui, 251 Cal. App. 2d 901, 909-10, 60 Cal. Rptr. 166, 170-71 (1967); Ralke Co. v. Esquire Bldg. Maint. Co., 246 Cal. App. 2d 141, 54 Cal. Rptr. 556 (1966).

109. Herrero v. Atkinson, 227 Cal. App. 2d 69, 75, 38 Cal. Rptr. 490, 493 (1964) ("Under such circumstances it is equitable and just that indemnity be allowed Herrero, and that the crossdefendant doctors and hospital bear that portion of the damages caused by their own negligent conduct').

110. San Francisco v. Ho Sing, 51 Cal. 2d 127, 330 P.2d 802 (1958). Ho Sing was the first California case to recognize a noncontractual right of indemnity among tortfeasors. The city had been compelled to pay a pedestrian for injuries received when she fell over a defective skylight in a sidewalk in front of defendant's premises. Although there was no contractual relationship between the city and the defendant, the court did emphasize the licensor-licensee relationship existing between them. Id. at 137, 330 P.2d at 808. Subsequent decisions have made it clear that such a special relationship between the tortfeasors is not a necessary prerequisite for recovcry of noncontractual indemnity. See Cobb v. Southern Pac. Co., 251 Cal. App. 2d 929, 932, 59 Cal. Rptr. 916, 918 (1967); Lewis Ave. Parent Teachers' Assn. v. Hussey, 250 Cal. App. 2d 232, 235-36, 58 Cal. Rptr. 499, 501-02 (1967); Herrero v. Atkinson, 227 Cal. A pp. 2d, 69, 74, 38 Cal. Rptr. 490, 492-93 (1964).

111. Cobb v. Southern Pac. Co., 251 Cal. App. 2d 929, 59 Cal. Rptr. 916 (1967) (recognized the right of an employer to recover indemnity from the person who created the dangerous working condition leading to an employee's injury).

112. A federal district court recently concluded that California would permit an owner or occupier held for his failure to provide safe premises to recover indemnity from the creator of the hazard. The court noted that in such a case the owner and lessor could recover under either the noncontractual theory or under the doctrine of implied contractual indemnity. See Great Am. 1ns. Co. v. Evans, 269 F. Supp. 151 (N.D. Cal. 1967).

113. American Can Co. v. San Francisco, 202 Cal. App. 2d 520, 21 Cal. Rptr. 33 (1962). The court affirmed an order striking an indemnty claim. American Can Company's driver had 
supervise, ${ }^{114}$ negligence of the claimant's agent, ${ }^{115}$ and failure of the claimant to provide safe premises. ${ }^{116}$ In all cases where the fault of the person seeking indemnity was greater than a simple failure to discover a hazard which the indemnitor had created, California courts, prior to Ryan, refused to grant it. ${ }^{117}$ The articulated bases of these California decisions depend largely on the indemnity category into which the case falls.

In deciding noncontractual indemnity cases, the California courts use the "primary-secondary" rubric to describe their conclusion that the claimant was not at fault or virtually without fault if they grant indemnity, or that he was substantially at fault if they refuse indemnity. Before Ryan, California courts relied on the Pennsylvania case of Builders Supply Co. v. McCabe, ${ }^{118}$ which staunchly refused to manipulate the "active-passive" verbiage to allow indemnity to the less negligent of two or more concurrently negligent tortfeasors. Certain Ianguage from this case has been quoted in virtually every major noncontractual decision rendered in California since I958:1"

The right of indemnity rests upon a difference between the primary and secondary liability of two persons each of whom is made responsible by the law to an injured party. It is a right which enures to a person who, without active fault on his part, has been compelled

negligently collided with an improperly parked municipal railway tower truck, injuring two individuals. The driver and American Can Company sought indemnity from the city. Relying on the distinction between passive and active negligence, the court found the complaint to rest in reality on a comparison of degrees of negligence, a theory which has been disapproved in California.

114. A claim for implied contractual indemnity which would otherwise be granted fails if the claimant is substantially at fault. Pierce v. Turner, 205 Cal. App. 2d 264, 23 Cal. Rptr. 115 (1962). The court, noting it was bound to assume that the evidence supported the finding of the trial court that Turner had negligently failed to supcrvise Pierce in his cutting, held such a finding precluded a right of indemnity.

115. A contractor seeking indemnity from its subcontractor on a theory of implied contractual indemnity has been denied recovery where the contractor's agent participated in the hazard created. Cahill Bros. v. Clementina Co., 208 Cal. App. 2d 367, 25 Cal. Rptr. 301 (1962).

116. O'Melia v. Calif. Prod. Serv,, Inc., 261 A.C.A. 717, 68 Cal. Rptr. 125 (1968). Defendant was an oil field repairer employed by plaintiff to fix one of his wells; hecause of the absence of certain safety latches one of the defendant's employees was injured. Plaintiff sought indemnity on the theory that defendant had breached an implied agreement to make the repairs safely. The court held tbat the plaintiff's fault in failing to provide a safe place to work by expressly directing the start of work despite the missing safety latches barred any indemnity claim.

117. However, there is some rather confused dicta in Aerojet Gen. Corp. v. D. Zelinsky \& Sons, 249 Cal. App. 2d 604, 611, 57 Cal. Rptr. 701, 706 (1967), suggesting that the indemnitee in that case was personally at fault.

118. 366 Pa. 322, 77 A.2d 368 (1951).

119. E.g.. Muth v. Urricelqui, 251 Cal. App. 2d 901, 908-09, 60 Cal. Rptr. 166, 170 (1967); Cahill Bros., Inc. v. Clementina Co., 208 Cal. App. 2d 367, 381-82, 25 Cal. Rptr. 301. 307 (1962). 
by reason of some legal obligation, to pay damages occasioned by the initial negligence of another, and for which he himself is only secondarily liable. The difference between primary and secondary liability is not based on a difference in degrees of negligence or on any doctrine of comparative negligence-a doctrine which, indeed, is not recognized by the common law. It depends on a difference in the charicter or kind of the wrongs which cause the injury and in the nature of the legal obligation owed by each of the wrongdoers to the injured person . . . .

. . . . But the important point to be noted in all the cases is that secondary as distinguished from primary liability rests upon a fault that is imputed or constructive only, being based on some legal relation between the parties, or arising from some positive rule of common or statutory law or because of a failure to discover or correct a defect or remedy a dangerous condition caused by the act of the one primarily responsible. ${ }^{120}$

The last sentence of this passage sums up the California courts' "primary-secondary" standard in noncontractual indemnity cases. It is in the area of implied contractual indemnity that the California courts have used "active-passive" terminology. ${ }^{121}$ It is important to note that the "active-passive" test is not used in California in the same way it has been in other jurisdictions. ${ }^{122}$ In California these labels perform a limited function: Where a contractual relationship exists between the parties and a promise to indemnify might be implied therefrom, "active-passive" are the labels used in deciding whether the person seeking indemnity has participated in the wrong to such an extent as to bar his indemnity claim. ${ }^{123}$ In other jurisdictions "active-passive" has been used to establish a right to noncontractual indemnity between concurrent tortfeasors by comparing degrees of fault. ${ }^{24}$ California courts have disavowed such balancing. ${ }^{125}$

120. Builders Supply Co. v. McCabe, 366 Pa. 322, 325-28, 77 A.2d, 368, 370-71 (1951) (citations omitted).

121. E.g. Muth v. Urricelqui, 251 Cal. App. 2d 901, 60 Cal. Rptr. 166 (1967); Cahill Bros. v. Clementina Co., 208 Cal. App. 2d 367, 382, 25 Cal. Rptr. 301, 309 (1962); Pierce v. Turner, 205 Cal. App. 2d 264, 23 Cal. Rptr. 115 (1962).

122. Compare Banks v. Central Hudson Gas \& Elec. Corp, 224 F.2d 631 (2d Cir. 1955), with American Can Co. v. San Francisco, 202 Cal. App. 2d 520, 21 Cal. Rptr. 33 (1962).

123. See Goldman v. Ecco-Phoenix Elec. Corp., 62 Cal. 2d 40, 44, 396 P.2d 377, 379, 41 Cal. Rptr. 73, 75 (1964); American Can Co. v. City \& Co. of San Francisco, 202 Cal. App. 2d 520, 524-25, 2 I Cal. Rptr. 33, 35-36 (1962); Alisal Sanitary Dist. v. Kennedy, 180 Cal. App. 2d 69, 4 Cal. Rptr. 379 (1960); cases citied note 121 supra.

124. See note 43 supra.

125. See Baldwin Contracting Co. v. Winston Steel Works, Inc., 236 Cal. App. 2d 565, 572, 46 Cal. Rptr. 421, 425 (1965); Cahill Bros., Inc. v. Clementina Co., 208 Cal. App. 2d 367, 381-82, 25 Cal. Rptr. 301, 307 (1962); American Can Co. v. San Francisco, 202 Cal. App. 2d 
Prior to Ryan the California indemnity provisions were reasonably clear and settled. Unless an express indemnity contract explicitly provided for indemnification of the claimant for his own negligence, the active participation of the indemnity claimant would bar his right to recover. In the absence of a contractual relationship, a concurrent tortfeasor was permitted to recover from his co-tortfeasor only if he was either totally without fault or only at fault for failure to discover and remedy a hazard created by the indemnitor.

\section{THE RYAN EPISODE: AN EVALUATION}

In City of Sausalito v. Ryan the city of Sausalito had been charged with negligent failure to provide a barrier between the roadway and the bay in violation of Government Code section 835. It

520, 525-26, 21 Cal. Rptr. 33, 36 (1962) (commenting on the implied contract cases); Alisal Sanitary Dist. v. Kennedy, 180 Cal. App. 2d 69, 75, 4 Cal. Rptr. 379, 383 (1960).

This difference in the use of "active-passive" explains the apparent conflict, see Comment. The Allocation of Loss Among Joint Tortfeasors, 41 S. CAL. L. Rev. ${ }^{-728,} 741-43$ (1968), between the United States Supreme Court's decision in Weyerhaueser S.S. Co. v. Nacirema Operating Co., 355 U.S. 563 (1958), and the California implied indemnity cases which rely upon it. In Weyerhaueser, the Supreme Court cited Ryan Stevedoring Co. v. Pan-Atlantic S.S. Corp., 350 U.S. 124 (1955), to the effect that: "In the area of contractual indemnity an application of the theories of 'active' and 'passive' as well as 'primary' and 'secondary' negligence is inappropriate." Id. at 569. This is apparently in conflict with California cases which talk in terms of "active-passive" negligence in deciding implied contractual indemnity cases. See Aerojet Gen. Corp. v. D. Zelinsky \& Sons, 249 Cal. App. 2d 604, 608, 57 Cal. Rptr. 701. 703 (1967); Baldwin Contracting Co. v. Winston Steel Works, Inc., 236 Cal. App. 2d 565, 57172, 46 Cal. Rptr. 421, 425 (1965); Cahill Bros. v. Clementina Co., 208 Cal. App. 2d 367, 382, 25 Cal. Rptr. 301, 307 (1962). However, the Ryan Court was referring to noncontractual indemnity and contrasting it with contractual indemnity. See Ryan Stevedoring Co. v. PanAtlantic S.S. Corp., 350 U.S. 124, 132-33 (1955).

California does not use the "active-passive" formula in noncontractual indemnity and limits its use in contractual indemnity to consider the participation of the claimant for implicd contractual indemnity to decide whether he is barred from recovering because of "active participation." Horn \& Barker, Inc. v. Macco Corp., 228 Cal. App. 2d 96, 104, 39 Cal. Rptr. 320, 325 (1964); Cahill Bros. v. Clementina Co., 208 Cal. App. 2d 367, 381-82, 25 Cal. Rptr. 301,307 (1962). Since the Weyerhaueser Court was referring to the common use of "activepassive" terminology as applied in noncontractual indemnity situations and condemning its use in contractual indemnity, the case is not inconsistent with the California cases which have a very limited definition of the "active-passive" test.

In Weyerhaueser the Court noted that the shipowner vas only "entitled to indemnity absent conduct on its part sufficient to preclude recovery." Weycrhauescr S.S. Co. v. Nacirema Operating Co., 355 U.S. 564, 567 (1958). In California conduct "sufficient to preclude recovery" is any conduct, including failure to supervise, involving personal fault beyond a mere failure to discover a hazard created by a third person. If the claimant is free of such fault his negligence is termed "passive" in contrast to the indemnitor's "active" negligence and recovery is granted. 
sought indemnity from its codefendants Ryan and Kelley, the negligent drivers involved in the accident, on a cross-claim for a declaratory judgment. The court relief heavily on the Ninth Circuit's decision in United Air Lines, Incorporated $v$. Wiener. ${ }^{126}$ Wiener weighed and compared degrees of fault and permitted a tortfeasor substantially at fault to shift the entire loss to a more culpable cotortfeasor. ${ }^{127}$ Following this reasoning the Ryan court reversed the sustaining of demurrers to the cross-complaint and concluded:

Likewise, here, the alleged liabilities to the plaintiff of Ryan and Kelley on one hand and the City, with its statutory obligations on the other, are based on breaches of different qualities of duties toward Gray. They can be considered to be on different [planes] of fault and this difference, if established at the trail, would warrant a complete shifting of the loss from one to the other. If the acts prove to be as here alleged, it would seem equitable and just that implied indemnity be allowed to the City against Ryan and Kelley..$^{128}$

This result introduced the standard of comparative culpability into the California law of implied indemnity for the first time, ${ }^{129}$ albeit only briefly. ${ }^{130}$ Previous California cases, following Builders Supply Company v. McCabe, ${ }^{131}$ had repudiated any notion of balancing degrees of fault. Since the Supreme Court of California did not express its approval or disapproval of such an extension of indemnity, ${ }^{132}$ an evaluation of the Ryan result may be helpful for future cases where such an extension is considered.

A situation such as that in Ryan, where several parties are participatively negligent, is inappropriate for the application of all-ornothing indemnity. Permitting the city to shift the entire loss to Ryan and Kelley undercuts important policy goals. Where several parties are substantially at fault, contribution is the appropriate remedy.

As a result of this decision, the city of Sausalito gets off scot free despite its flagrant violation of a public safety law. This dilutes the

126. 335 F.2d 379 (9th Cir. 1964).

127. See note 48 supra and accompanying text.

128. 258 A.C.A. at 98.

129. As Judge Molinari, who was involved in many of the prior indemnity cases, observed: "The thrust of the decision appears to be, however, that in California, indemnity may be predicated upon the basis of the disparity in the contrasted gravity of fault: Such a rule is clearly an expansion of the doctrine of implied indemnity as heretofore recognized by the California cases." Molinari, supra note 12, at 167.

130. The Ryan case had precedential force in California between the time the decision was rendered and the time that the California supreme court granted a hearing. At the time the hearing was granted the court of appeals decision was automatically vacated. See note 3 supra.

131. Discussed at notes 119-20 supra and accompanying text.

132. See note 1 supra. 
city's incentive to maintain its streets bordering on the bay in a safe condition. ${ }^{133}$ It may be debatable whether tort damages can be effective as a deterrent, given the widespread use of liability insurance. And deterrence is probably not the predominant tort policy goal today. ${ }^{134}$ However, a recent commentator found underlying the indemnity cases an attempt to serve the goal of deterrence. ${ }^{355}$ The Ryan case must be labeled a derelict in such a scheme. To the extent that tort Iaw is designed to deter negligence and promote safety, the Ryan rule undermines its effectiveness.

Even if one argues that deterrence is unrealistic because of liability insurance, the Ryan decision is not justified. It also runs counter to the goal of spreading the loss over as large a segment of society as possible. On the one hand, if, as Professor James argues, recovery is sought by a good loss distributor against a poor one, granting indemnity to the city would be undesirable. On the other hand, when as here all the parties are good Ioss distributors, the goal of maximum spreading would be best accomplished by granting contribution; the loss would then be spread among not only automobile insurance premium payers but also among all the taxpayers of the city.

The grant of indemnity in Ryan also undercuts the restitutional basis of both contribution and indemnity. The city, whose fault contributed substantially to the resulting death, is allowed to escape all payment because it is fortunate enough to be able to point to others whose fault was even greater. Ryan and Kelley are burdened with the entire wrongful death damages despite the fact that but for the city's negligence no one would have drowned. Indemnity should not have been invoked to enrich the city at the expense of Ryan and Kelley.

133. This danger was powerfully voiced by the dissent in the first noncontractual indemnity case, San Francisco v. Ho Sing, 51 Cal. 2d 127, 330 P.2d 802 (1958), which held that the city could recover indemnity from the creator of a sidewalk hazard despite its duty of inspection. Justice Shauer objected: "If such a right is created and enforced by this court, a most natural result will be encouragement of laxity on the part of the City in carrying out its obligation of inspection, discovery of patent defects, and proper maintenance of sidewalks for the safety of the public." Id. at 140-41, 330 P.2d at 810.

The argument was less persuasive there than it is in Ryan because of the impossibility of inspecting well enough to prevent an abutting land owner from creating a menace which could cause injury before discovered by the city. Such an inspection burden would he impossible. Failure to erect a barrier to provide safety on the roads next to the Bay is another matter.

134. J. Fleming, supra note 2, at 6-20. Buf cf. Calabresi, The Decision For Accidents: An Approach 10 Nonfault Allocation of Cosis, 78 HARv. L. Rev. 713, 742-45 (1965).

135. See Comment, Ihe Allocation of Loss Among Joint 7ortfeasors, 4l S. CAL. L. Rev. 728,746 (1968). 
Nevertheless, certain weaknesses in the California contribution statutes create pressure to extend indemnity to this type of situation where both parties are substantially at fault. This may largely explain the Ryan result.

The parties in a multiple tort action are pressed to formulate an indemnity claim rather than take chances on contribution. A defendant can cross-claim for indemnity in the original action but not for contribution. ${ }^{136}$ Parties may want to get everything cleared up in one action in order to save time, money, and avoid inconvenience. A potential contribution claimant knows that he may lose out completely if the plaintiff drops his action against the other defendant(s), because the claimant has no right until a joint judgment has been rendered and he has paid more than his pro rata share. ${ }^{137}$ These factors, coupled with the limitation to pro rata sharing even if contribution is obtained, cause defendants to focus their efforts on trying to establish a case for indemnity rather than contribution.

Similarly, the courts may feel pressure to grant indemnity because of the inadequacy of California's contribution provisions. If, for example, the plaintiff has named only the less negligent of the parties, the judge knows that unless he allows indemnity and forces the more negligent party to pay all the damages the less negligent party will be fully liable without the possibility of recovering contribution due to California's joint judgment requirement. ${ }^{138}$ Additionally, even where contribution can be obtained, California's requirement of equal shares for all defendants ${ }^{139}$ may work injustice, thus further encouraging a judge to stretch a grant of indemnity. For example, in Ryan the court may have felt that the city was only 10 percent at fault and, therefore, that it was fairer to grant indemnity than to require the city to pay $1 / 3$ of the loss.

\section{V}

\section{PROPOSED STATUTORY CHANGES}

The changes in Code of Civil Procedure sections 875-80 necessary to provide for effective handling of multiple party tort situations in California are few and simple, though crucially important.

The requirement of a joint judgment before a right to

136. See notes 87-89 supra.

137. See note 91 supra.

138. See notes 84 and 85 supra and accompanying text.

139. Cal. Civ. Pro. Code $§ 876$ (West Supp. 1969). 
contribution can arise should be abolished for the reasons outlined previously. ${ }^{140}$ Instead, a right to claim either contribution or indemnity should arise at the time the plaintiff's action is first brought. However, a claimant should lose this right with respect to any co-tortfeasor subject to the court's jurisdiction against whom he has failed to cross-claim in the original action. If the cross-complaints are too unwieldy to handle in the same action, or if the plaintiff's claims might be jeopordized by confusing the jury with evidence on the cross-claims, section 1048 of the Code of Civil Procedure provides a ready mechanism for a judge to sever these two aspects of the case for separate hearing. ${ }^{141}$

Michigan recently adopted what amounts to a compulsory counter-claim for contribution in order to correct the evils of its joint judgment requirement. ${ }^{142}$ California should follow this lead. Such a scheme presents a myriad of advantages. The proposal continues to eliminate any possibility of inconsistent verdicts, one of the alleged justifications for the joint judgment rule. However, it has the added advantage of judicial economy by seeking to handle all issues arising from the same transaction in one action.

The proposal eliminates the plaintiff's power to decide who will bear the loss. 1t substitutes a rule of law and takes away the temptation for collusion between a plaintiff and one of the wrongdoers. This change would also eliminate most present problems which arise regarding the res judicata effect of the original tort action in the subsequent action for indemnity or contribution. ${ }^{143}$ The only case where the problem would remain would be the rare one where a potential indemnitor or contributor was beyond the jurisdiction of the court trying the original tort claim and the defendant later brought a separate action to enforce his right.

In addition, section 876 should be amended to provide apportionment of the damages among the tortfeasors in proportion to

140. See text accompanying notes 79-96 supra.

141. Cal. Civ. Pro. Code $\S 1048$ (West 1955).

142. See Mich. Comp. Laws AnN. $\$ 600.2925$ (West 1968); Mich, Gen. Cr. R. 204.1(I), in J. Honigman \& C. Haivkins, Mich. CT. Rules ANN. 503-04 (2d ed. 1962).

143. The problem is: What effect does the first damage judgment have in a subsequent indemnity or contribution action? Res judicata problems assume a myriad of forms. The most common one has arisen when an indemnity defendant contends that the initial action establishing the indemnity plaintiff's liability to the tort vietim is a conclusive bar to indemnity because it establishes his "active negligence." The cases have rejected this contention. Muth v. Urricelqui, 25I Cal. App. 2d 90I, 907, 60 Cal. Rptr. 166, 169 (1967); Ralke Co. v. Esquire BIdg. Maint. Co., 246 Cal. App. 2d 141, 145, 54 Cal. Rptr. 556, 559 (1966); Baldwin Contracting Co. v. Winston Steel Works, Inc., 236 Cal. App. 2d 565, 571, 46 Cal. Rptr. 421, 425 (1965). 
their degree of contributing fault. Where such a determination is not practicable, the tortfeasors should be deemed equally responsible.

Such a provision is consonant with the purpose of contribution: to spread the loss equitably among all those who contributed to it. ${ }^{144}$ It is no serious challenge to say that it may be difficult or unrealistic to assess percentage of fault to the nearest percent. ${ }^{145}$ The point is that proportional contribution would make it possible to assess damages in accord with a determination that one party was only 10 percent at fault and the other 90 percent at fault. Under the present California system of contribution, one is limited in such a case to two rigid alternatives: either grant 50 percent contribution to each or grant full indemnity. to the less negligent tortfeasor. As a recent commentator observed:

If a fact situation arises in which joint tortfeasors are clearly neither equally culpable between themselves nor does culpability rest wholly with one tortfeasor, and such fact. situations are by no means rare, then it quickly becomes obvious that to award either equal contribution or indemnity results in unjust enrichment for one of the tortfeasors. Neither option can be awarded in such a situation without doing precisely the evil the equitable remedy was drawn to prevent . . . . .16

Such a system has worked well in other countries and other American jurisdictions. ${ }^{177}$ It should be adopted in California.

These proposals are not entirely new, ${ }^{148}$ but the need for their adoption is more pressing today than ever before. The growing number of torts involving multiple parties ${ }^{199}$ calls for an effective means of allocating the loss among the responsible parties. The Baldwin Hills

144. See notes 5 and 16 supra and accompanying text.

145. Comment, The Allocation of Loss Among Joint Tortfeasors, $41 \mathrm{~S}$. CAL. L. REv. 728, 747 (1968).

146. Furnish, supra note 5 , at 50 .

147. See notes 8 \& 9 supra and accompanying text; J. Fleming, THE LAw OF TORTS 688, 690-91 (3d ed. 1965); Cohn, Responsibility of Joint Wrongdoers in Continental Laws, 51 LAw. Q. REv. 468, 496-98 (1935); Turck, Contribution Between Tortfeasors in American and German Lan-A Comparative Study, 41 TuL. L. Rev. 1, 28 (1966).

148. See Thaxter, Joint Tortfeasors: Legislative Changes in the Rules Regarding Releases and Contributions, 9 HAST. L. REv, 180 (1958); Tuft, Contribution Between Joint Tortfeasors: A Legislative Proposal: Procedure, 24 Calif. L. Rev. 702 (1936); Tuft, Contribution Between Joint Tort feasors: A Legislative Proposal, 24 CALIF. L. Rev. 546 (1936).

Attempts have been made and thwarted in the California Bar Association to sponsor amendments to the contribution statutes which would eliminate California's joint judgment requirement by permitting a defendant to cross-complain for contribution in the original action. 37 CAL. S.B.J. 370 (1962); 38 CAL. S.B.J. 152 (1963).

149. See note 2 supra. 
dam disaster ${ }^{150}$ and the ensuing emergency legislation ${ }^{151}$ made it perfectly clear that the present California provisions on contribution are inadequate to handle the problems. A special law was passed to provide for contribution before joint judgment for claims arising out of the dam's collapse. The statute's constitutionality was challenged, and the court emphasized that the statute had been necessary since, "The general contribution statute deters such settlements because under Code of Civil Procedure section 875 a tortfeasor who settles a claim before rendition of judgment therefore loses his right to seek contribution against other persons who may be liable for the same injury." 152 The argument was then made that if the change were needed it should have been made for all claims, not just those arising out of this one disaster. The court's answer was that such a change, while promoting out-of-court settlement, would promote a multiplicity of litigation because it would permit a tortfeasor to bring a contribution action against parties not named in the judgment. lssues of liability and damages would then have to be relitigated..$^{153}$ This objection could be easily eliminated by the proposed compulsorycounterclaim rule.

\section{CONCLUSION}

As long as our present tort system is retained, an effective contribution and indemnity scheme is necessary to handle the growing problems created by multiple tort liability. The present contribution statutes of California, with their tendency to produce a Ryan result, do not allocate the ultimate loss among the tortfeasors in a fair and equitable way. The present system runs counter to tort policy goals of deterrence, equitable loss sharing by all the wrongdoers, effective loss distribution over a large segment of society, and rapid compensation of the plaintiff-as well as the judicial economy interest in settling all matters arising out of the same transaction in one proceeding.

The proposed restriction of indemnity to its pre-Ryan bounds coupled with the proposed compulsory counterclaim for both indemnity and contribution, the abolition of a joint judgment requirement for contribution, and allocation of contribution proportional to fault does provide for fair and equitable sharing of the

150. N.Y. Times, Dec. 15, 1963, at 1, col. 4.

151. See note 72 supra and accompanying text. (1968).

152. Los Angeles v. Standard Oil Co., 262 A.C.A. 144, 150, 68 Cal. Rptr. 512, 515

153. Id. at 150-51, 68 Cal. Rptr. at 515-16. 
loss among concurrent tortfeasors. It promotes important tort policies, exemplifies the very basis of the contribution and indemnity doctrines, and contributes to reducing court dockets by promoting settlement and disposition of all related claims in the same action. A Ryan kind of indemnity extension should be avoided and the contribution statutes revised.

Robert G. Werner 